\title{
Effects of Different Drying Methods on Quality Traits of Hanwoo Beef Jerky from Low-Valued Cuts during Storage
}

\author{
Dong-Gyun Lim¹, Sang-Suk Lee, Kang-Seok Seo, and Ki Chang Nam* \\ Department of Animal Science and Technology, Sunchon National University, Suncheon 540-742, Korea \\ ${ }^{1}$ Department of Health Administration, Jinju Health College, Jinju 660-757, Korea
}

\begin{abstract}
To determine the effects of various drying methods on the quality characteristics of beef jerky from low-valued cuts, Hanwoo beef shank muscles were either hot air-dried, shade-dried, or sun-dried. The physicochemical quality and microbiological safety of the Hanwoo beef jerky were analyzed during a storage of $25^{\circ} \mathrm{C}$. Moisture content and water activity $\left(\mathrm{a}_{\mathrm{w}}\right)$ of the samples decreased as the time period of storage increased, regardless of the drying condition $(p<0.05)$. Shade-dried jerky showed higher $\mathrm{a}_{\mathrm{w}}$ compared to others after storage of $20 \mathrm{~d}(p<0.05)$. The $\mathrm{pH}$ value of hot air-dried jerky was higher than those of others $(p<0.05)$. For color properties, sun-dried samples showed higher redness $\left(\mathrm{a}^{*}\right)$ and yellowness $\left(\mathrm{b}^{*}\right)$ compared with the properties of others $(p<0.05)$. The hot air-dried jerky showed higher shear force values than the sun-dried or the shade-dried jerky after 10 and $20 \mathrm{~d}(p<0.05)$. However, the total plate counts (TPCs) of naturally dried jerky (shade and sundried) were higher than hot-air dried jerky after storage of 10 and $20 \mathrm{~d}(p<0.05)$. With regard to sensory properties, naturally dried jerky showed higher tenderness, juiciness, and overall acceptability scores than the hot air-dried jerky $(p<0.05)$. In conclusion, although natural drying appears to be more susceptible to microbiological contamination than hot air-drying, the natural drying method seems to result in superior quality than the hot air drying method.
\end{abstract}

Key words: beef jerky, hot air-dried, sun-dried, shade-dried, meat quality

\section{Introduction}

Jerky is a traditional food that has been consumed by human beings at least since ancient Egypt. The word "jerky" came from the Spanish word "charque" (FSIS, 2011). Jerky is historically one of the oldest forms of preserved meat, by curing and drying to reduce $\mathrm{a}_{\mathrm{w}}$ and hence retard microbial growth (Choi et al., 2008). Jerky is a nutrient-dense meat product that is easy to prepare, lightweight, and is shelf-stable without refrigeration (Fernández-Salguero et al., 1994; Yoon et al., 2005). Because it is nutritious (high in protein and iron, low in fat), shelfstable (0.75-1.0 moisture protein ratio) due to low water content, and known as microbiologically safe $\left(<0.91 \mathrm{a}_{\mathrm{w}}\right)$, jerky is in high demand as a popular food and widely available to sports enthusiasts, travelers, mountaineers and consumers (Calicioglu et al., 2003; Fernández-Salguero et al., 1994). However, although the moisture con-

\footnotetext{
*Corresponding author: Ki-Chang Nam, Department of Animal Science and Technology, Sunchon National University, Suncheon 540-742, Korea, Tel: 82-61-750-3231, Fax: 82-61-7503230, E-mail: kichang@scnu.kr
}

tent of jerky is low, there are still microbial safety problems during marketing and distribution (Park et al., 2009). First of all, the primary concern when producing jerky is to combine its good sensory quality with an appropriate shelf life. Guidelines have been developed to implement an assurance health safety system, Hazard Analysis Critical Control Point (HACCP), in commercial production of jerky products (HACCP, 1997).

A considerable number of studies have been conducted using raw meat such as beef, pork and poultry, using various processing techniques, for example, the condition of the raw meat (Farouk and Swan, 1999; Igene et al., 1990), the marination method (Albright et al., 2003; Calicioglu et al., 2003), the drying conditions (Konieczny et al., 2007), and the use of sliced or ground meat (Barrett et al., 1997). Various jerky products can be produced using several types of meats such as pork, poultry (Lee and Kang, 2003) and game animals. Although beef jerky is more widely produced than other types of jerky from different species (Calicioglu et al., 2003; Konieczny et al., 2007), jerky made from other types is increasing (Yang and Lee, 2002). Also, jerky can be produced from sliced (e. g. whole-muscle jerky), or ground (e. g., re-structured 
or formed jerky) portions of lean meat (Faith et al., 1998). Whole muscle jerky products may be too dry or brittle, and may have the undesirable color typical of over-dried meats (Miller et al., 1996). Some comminuted jerky-type products have a softer texture, high fat and high $a_{w}$, resulting in activation of lipid oxidation and microorganism (Quinton et al., 1997).

Jerky is the result of application of the so-called hurdle technology which involves factors such as temperature, water activity, and preservatives such as organic acids and spices in the preparation (Fernández-Salguero et al., 1994; Leistner, 1987). Intermediate moisture (IM) meat products such as jerky can be preserved by salting and drying to reduce water activity. Drying is the world's oldest and most common method of food preservation in production of meat and meat products. By drying, the IM meat products reach $\mathrm{a}_{\mathrm{w}}$ of $0.6-0.9$ equivalent to a $\mathrm{RH}$ of $60-90 \%$ at ambient temperature and the growth of microorganisms can be efficiently inhibited by a low $\mathrm{a}_{\mathrm{w}}$ system (Chang et al., 1996).

There are several types of drying methods in the process of making jerky. For example, natural drying, hot and cold air-drying, vacuum drying, freeze-drying and so on can be used (Edward and Pauline, 1965; Holdsworth, 1971; Karel et al., 1978; Kim, 1990; Labelle and Moyer, 1996). Two types of natural drying are used mainly, which is sun and shade drying as traditional system. Both sun and shade-drying occur in the air, only shade one occurs without heat. Sun-drying sometimes takes place in a special container that catches and captures the sun's heat. These types of drying are used mainly for fruits such as apricots, tomatoes, and grapes. However, it is not recommended for making meat jerky due to a lack of a steady heat source and the potential for contamination from animals, insects, dust, and bacteria (FSIS, 2011). Furthermore, this traditional process could be very time-consuming in drying and hard to control moisture contents (Holdsworth, 1971; Lee and Park, 2004; Park et al., 2002). Hot air-drying from an artificial heat source is commonly used in the meat processing plants and done by placing food in either a warm oven or a food dehydrator (FSIS, 2011). This drying method is useful to inhibit the growth of microorganisms by lowering moisture contents during the hot air-drying process and prompt-dried evenly (Kim, 1990; Labelle and Moyer, 1966). However, it has some disadvantages of not only surface hardening by this rapid drying and deterioration in meat quality such as flavor and texture due to Maillard reaction (Kim, 1990; Labelle and Moyer, 1966), but also it is more susceptible to lipid oxidation and meat color with increasing drying time and temperature. Hot air-drying also requires high cost of energy to produce high temperature of air. So far, there have been few attempts to assess the quality and microbiological aspects of Hanwoo beef jerky produced under different drying conditions.

In recent years, tenderloin and sirloin in beefs are the most demanding and popular cuts in most Korean meat consumers and consequently their retail prices are much higher than other cuts such as shank. On the other hand, the parts are often regarded as a low-preference beef cuts and utilized for processed meat products. As a result, these low-valued beef cuts should be utilized by developing an acceptable jerky product. Therefore, the aim of the study was to investigate effects of various drying methods on the physicochemical quality and microbiological safety of Hanwoo beef jerky from low-valued cuts during storage.

\section{Materials and Methods}

\section{Preparation of beef jerky}

Four fresh Hanwoo beef shank muscles (Goheung, Jeonnam province) were randomly purchased from local retail shops to make 4-replication and were frozen at $-45^{\circ} \mathrm{C}$ until analysis. Prior to $1 \mathrm{~d}$, the frozen beef samples were thawed until internal temperature reached $-1{ }^{\circ} \mathrm{C}$ in the refrigerator, sliced to $0.5 \mathrm{~cm}$ thick pieces with a meat slicer (HFS 350G, Hankook Fugee Industries Co. Ltd., Korea) and cut into cubes. Sliced jerky samples were cut parallel in direction to muscle fibers and all subcutaneous and intermuscular fat and visible connective tissue were removed from the fresh muscles. The formulation in production of Hanwoo beef jerky is presented in Table 1. The manufacturing process of Hanwoo beef jerky is as follows. The sliced beef samples were then cured for $24 \mathrm{~h}$

Table 1. Formula of Korean beef jerky

\begin{tabular}{lcc}
\hline \hline \multirow{2}{*}{ Ingredient } & \multicolumn{2}{c}{ Proportion } \\
\cline { 2 - 3 } & Amount $(\mathrm{g})$ & $(\%)$ \\
\hline Beef & 1,000 & 81.5 \\
Water & 118.8 & 9.7 \\
Sodium chloride & 50 & 4.1 \\
Brown sugar & 40 & 3.3 \\
Sodium nitrite & 0.05 & 0.004 \\
Phosphates & 0.5 & 0.04 \\
Ginger powder & 5 & 0.4 \\
Onion powder & 5 & 0.4 \\
Garlic powder & 5 & 0.4 \\
Black pepper & 2 & 0.2 \\
\hline
\end{tabular}


in a cure solution. All cured muscle samples were mixed using a mixer (5K5SS, KitchenAid Co. Ltd., USA) for 1 min and aged for $24 \mathrm{~h}$ in refrigerated temperature. After aging, all cured muscles samples were dried by 3 types of drying methods for the experiments. Control was dried by placing them for $4 \mathrm{~h}$ at $80^{\circ} \mathrm{C}$ in a hot air drier (DH.WON01155, Daihan Co., Korea) until a 0.7-0.75 $\mathrm{a}_{\mathrm{w}}$ is achieved. Sun-dried treatment was dried directly in the sun with autumn breezes at a temperature of $25-28^{\circ} \mathrm{C}, 26-$ $28 \%$ relative humidity for $3.5 \mathrm{~h}$. Shade-dried treatment was dried in open air without heat at a temperature of 15 $20^{\circ} \mathrm{C}, 25-30 \%$ relative humidity for $12 \mathrm{~h}$. In case of hotair drying, cooling to ambient $\left(24^{\circ} \mathrm{C}\right)$ temperature for 30 min, the jerky samples were loosely packed in oxygen impermeable plastic bags (single package), display to laying flat on the desk and stored at room temperature for up to $20 \mathrm{~d}$.

\section{Moisture contents and $\mathbf{a}_{\mathbf{w}}$}

Moisture content was obtained with a slightly modified method of AOAC methods (AOAC, 2000). The total moisture content of $3 \mathrm{~g}$ of finely chopped samples placed in aluminum moisture dishes were determined from their pre-dry and dry weights (dried in an air oven at $104^{\circ} \mathrm{C}$ for $24 \mathrm{~h}$ ) and expressed as the percentage of pre-dry weight and gram water per gram dry weight. The moisture content was determined in triplicate on each jerky product. Three pieces of the dried jerky samples from each treatment were selected and cut into small pieces using sharp scissors and were homogenized prior to measurement of water activity. The pieces were put into awcups, and their water activities determined with a awmeter (BT-RS1, Rotronic, Switzerland), calibrated at ambient temperature $\left(25^{\circ} \mathrm{C}\right)$ with distilled water $\left(\mathrm{a}_{\mathrm{w}}=0.999\right)$

\section{pH}

The $\mathrm{pH}$ of samples was determined with a $\mathrm{pH}$ meter (Orion 2 Star, Thermo scientific, USA). The $\mathrm{pH}$ values of jerky were measured by blending a 3 g sample with 27 $\mathrm{mL}$ distilled water for $60 \mathrm{~s}$ in a homogenizer (Polytron PT 10-35 GT, Kinematica, Switzerland). The $\mathrm{pH}$ meter was calibrated daily with standard buffers of $\mathrm{pH} 4.0$ and 7.0 at $25^{\circ} \mathrm{C}$.

\section{Instrument color}

The surface color value of the jerky samples were measured by the CIE L*, a* and $b^{*}$ system using a Minolta chromameter (Model CR-410, Minolta Co. Ltd., Japan), with measurements standardized with respect to a white calibration plate $\left(\mathrm{L}^{*}=89.2, \mathrm{a}^{*}=0.921, \mathrm{~b}^{*}=0.783\right)$ after $30 \mathrm{~min}$ blooming at room temperature. Color measurements for each of three replicates were taken and the $\mathrm{L}^{*}$, $a^{*}$ and $b^{*}$ value was recorded.

\section{Shear force measurement}

The Jerky samples were prepared a cubic form $(20 \times 20$ $\times 10 \mathrm{~mm}$ ) and heated during $90 \mathrm{~s}$ in electrical grill (Nova EMG-533, 1,400W, Evergreen enterprise, Korea). Internal temperature of the samples during heating was $72^{\circ} \mathrm{C}$ $\pm 2^{\circ} \mathrm{C}$ and then cooled for $30 \mathrm{~min}$ at room temperature. Each sample was cut perpendicular to the longitudinal orientation of the muscle fiber with a Warner-Bratzler shear attachment on a texture analyzer (TA-XT2i, Stable Micro System Ltd., U.K.), and measured the maximum shear force (unit : $\mathrm{kg}$ ). Test and pre-test speeds were set at $2.0 \mathrm{~mm} / \mathrm{s}$. Post-test speeds were set at $5.0 \mathrm{~mm} / \mathrm{s}$. Data were collected and analyzed from the shear force values to obtain for the maximum force required to shear through each sample.

\section{TBARS (2-thiobarbituric acid reactive substance)}

The TBARS of jerky samples were analyzed by the method described by the procedure of Ahn et al. (1998). A $2.5 \mathrm{~g}$ jerky sample was homogenized using a homogenizer (Polytron PT 10-35 GT, Kinematica Co., Switzerland) with $15 \mathrm{~mL}$ of distilled water for $2 \mathrm{~min}$ and then transferred to a $100 \mathrm{~mL}$ falcon tube. $1 \mathrm{~mL}$ of solution was placed in test tubes and $50 \mu \mathrm{L}$ buylated hydroxytoluene $(7.2 \%$ in ethanol, w/v) and $2 \mathrm{~mL}$ thiobarbituric acid/trichloroacetic acid solution (20 mM TBA/15\%, w/v) were added to the tubes. The mixture was vortexed and then incubated in a $90^{\circ} \mathrm{C}$ boiling water bath for $15 \mathrm{~min}$ to develop color. The sample was cooled in cold water for $10 \mathrm{~min}$, and centrifuged for $15 \mathrm{~min}$ at 3,000 $\mathrm{g}$. The absorbance of the resulting supernatant solution was determined at $531 \mathrm{~nm}$ against a blank containing all the reagents minus the sample. One $\mathrm{mL}$ of distilled water was added to test tube and mixed with $2 \mathrm{~mL}$ of TBA/TCA solution for blank sample. The TBARS was determined in triplicate on each jerky product. The amount of color was measured in a UV spectrophotometer (T60 U., Karaltay Scientific Instruments Co., China). The results were expressed as $\mathrm{mg}$ malonedialdehyde/kg sample.

\section{Microbiological analysis}

The jerky samples were analyzed by the method described by the procedure of Ahn et al. (1998). A 2.5 g jerky sample was homogenized. The jerky samples (10 g) were 
placed in $90 \mathrm{~mL}$ sterilized peptone water $(1 \%$ sterile peptone, $\mathrm{w} / \mathrm{v}$ ) in a stomacher bag. Samples were then homogenized using a stomacher (Interscience BagMixers, USA) for 2 min and diluted with peptone water for a microbial count. One $\mathrm{mL}$ of stomached and serially diluted with saline solution by 10 -fold was plated in triplicates. Total aerobic bacteria counts and E. coli. counts were determined by plating the diluted samples onto plate count agar (PCA, Difco, USA) and incubating the plates at $37^{\circ} \mathrm{C}$ for $48 \mathrm{~h}$. Each microbial count was the mean of three determinations. Microbial colonies were counted and expressed as colony forming units per gram of sample (CFU/g).

\section{Sensory evaluations}

The sensory scores were evaluated independently by 8 trained sensory panelists for each sample after $10 \mathrm{~d}$ of storage using a nine-point quantitative descriptive method, varying from dislike/weak extremely (score 1) to like/ strong extremely (score 9). The mean value from three repeated measurements was determined.

\section{Statistical methods}

An analysis of variance were performed on all the variables measured using the General Linear Model procedure of the SAS statistical package (SAS Inst., 1999). The Duncan's multiple range test $(p<0.05)$ was used to determine differences among the treatment means.

\section{Results and Discussion}

\section{Moisture contents and $\mathbf{a}_{\mathbf{w}}$}

One of the most important attributes of jerky products is moisture content (Yang et al., 2009). Changes in moisture content and $\mathrm{a}_{\mathrm{w}}$ of beef jerky with different drying methods during storage are shown in Table 2. In the present experiment, drying process of beef jerky has finished by reaching below $0.75 \mathrm{a}_{\mathrm{w}}$ to be given under the similar drying condition between control and treatments. Due to the effect of drying for $4 \mathrm{~h}$ at $80^{\circ} \mathrm{C}$ in a hot air drier, moisture content and $\mathrm{a}_{\mathrm{w}}$ of hot air-dried samples decreased as the storage period increased. The similar pattern of moisture content and $\mathrm{a}_{\mathrm{w}}$ was observed in sundried samples. Initial moisture content and $\mathrm{a}_{\mathrm{w}}(0 \mathrm{~d})$ of sun-dried one was the lowest among the treatment. Similar findings were obtained by Choi et al. (2008) who observed that $\mathrm{a}_{\mathrm{w}}$ of hot air-drying jerky in plastic packaging decreased as the storage period increased. Also, Jung et al. (1994) investigated that moisture content and $\mathrm{a}_{\mathrm{w}}$ of
Table 2. Moisture content and $a_{w}$ of beef jerky with different drying methods during storage

\begin{tabular}{lcccc}
\hline \multirow{2}{*}{ Treatment } & \multicolumn{3}{c}{ Storage (d) } & \multirow{2}{*}{ SEM $^{1)}$} \\
\cline { 2 - 4 } & \multicolumn{5}{c}{10} & 20 & \\
\hline Moisture (\%) & & \\
Hot air & $19.65^{\mathrm{x}}$ & $19.26^{\mathrm{bx}}$ & $14.27^{\mathrm{y}}$ & 1.73 \\
Sun-dried & $18.14^{\mathrm{x}}$ & $18.36^{\mathrm{cx}}$ & $14.90^{\mathrm{y}}$ & 1.12 \\
Shade-dried & $21.19^{\mathrm{x}}$ & $20.70^{\mathrm{ax}}$ & $16.70^{\mathrm{y}}$ & 0.15 \\
SEM & 1.82 & 0.72 & 2.05 & \\
\hline \multicolumn{5}{c}{ Water activity } \\
Hot air & $0.744^{\mathrm{x}}$ & $0.715^{\mathrm{x}}$ & $0.664^{\text {by }}$ & 0.023 \\
Sun-dried & $0.708^{\mathrm{x}}$ & $0.701^{\mathrm{x}}$ & $0.671^{\text {by }}$ & 0.008 \\
Shade-dried & $0.765^{\mathrm{x}}$ & $0.728^{\mathrm{y}}$ & $0.701^{\mathrm{ay}}$ & 0.011 \\
SEM & 0.033 & 0.029 & 0.017 & \\
\hline
\end{tabular}

${ }^{1}$ Standard error of the means $(n=12)$

${ }^{\mathrm{a}-\mathrm{c}}$ Figures with different letters within the same column differ significantly $(p<0.05)$.

${ }^{x, y}$ Figures with different letters within the same row differ significantly $(p<0.05)$.

jerky decreased during storage. Furthermore, Paterson et al. (1988) reported that a decrease in $\mathrm{a}_{\mathrm{w}}$ of jerky during storage may be due to sodium compounds as component of curing agents. In the study of Bone (1973) and Chang et al. (1996), the $\mathrm{a}_{\mathrm{w}}$ of jerky generally ranged from 0.65 to 0.90 . In this investigation, the $a_{w}$ values of sun-dried samples were very similar to the values of about 0.70 found by Torres et al. (1994) for the Charqui, a typical Brazilian meat product obtained by salting and sun-drying beef jerky under the similar condition.

There were no differences observed in moisture contents during 0 and $10 \mathrm{~d}$ of storage, regardless of the drying condition. However, there were significant differences after storage of $20 \mathrm{~d}$, shade-dried jerky showed significantly higher $\mathrm{a}_{\mathrm{w}}$ than sun-dried and hot air-dried sample $(p<0.05)$, which may be due to the water evaporation that could be caused by low relative humidity $(20 \%)$ during storage. In case of shade-dried one, it has a difficulty in the process of jerky production, due to the long-term drying (more than $12 \mathrm{~h}$ ). In general, commercial intermediate moisture foods have moisture contents of $17 \%$ to $25 \%$ (Chen et al., 2004; Jose et al., 1994; Jung et al., 1994) and similar results were obtained in this investigation. When producing jerky products, it is crucial to control the moisture contents because $a_{w}$ is closely related to moisture contents (Leistner, 1987). Jerky products need to have a stable $\mathrm{a}_{\mathrm{w}}$ to avoid changes in quality during storage (Yamaguchi et al., 1986). Normally, jerky manufacturing methods include addition of meats with humectants to lower $\mathrm{a}_{\mathrm{w}}$ (Chang et al., 1996). The composition of jerky 
products is controlled by use of humectants, which prevent migration of moisture. Eventually, it may be postulated that a decrease in moisture contents during storage could be attributed to no use of humectants in the process of beef jerky production. As presented in Table 2, $a_{w}$ of shade-dried one was the highest among the treatment after storage of $20 \mathrm{~d}$. The similar pattern of moisture content and $\mathrm{a}_{\mathrm{w}}$ decrease observed in shade-dried samples during storage significantly $(p<0.05)$, but, they resulted in slight decreases among the treatment. This result may be due to the low temperature and shade condition.

\section{pH and TBARS}

Changes in $\mathrm{pH}$ and TBARS values of beef jerky with different drying methods during storage are presented in Table 3. The $\mathrm{pH}$ values of jerky generally ranged from 5.94 to 6.28 . The $\mathrm{pH}$ value of hot air-dried jerky was significantly higher than those of other jerky samples $(p<0.05)$. Similar findings were obtained by Lee et al. (1997) who found out that as the drying temperature increased, hot air-dried jerky caused a significant increase in $\mathrm{pH}$ values. The high levels of $\mathrm{pH}$ value seem to be due to the denaturation in meat protein by heating and dehydration (Lee et al., 1997). There were no significant differences in $\mathrm{pH}$ values during the storage periods, regardless of various drying methods. In this study, storage time resulted in small-decreases in $\mathrm{pH}$ (a range of different final $\mathrm{pH}$ values 5.97-6.28). Jose et al. (1994) reported that the $\mathrm{pH}$ for beef jerky products was in the broad range of 4.72-6.73. Yang and Lee (2002) observed that the $\mathrm{pH}$ of commercial beef jerky samples was within the range of 5.4-5.8. Sev-

Table 3. pH and TBARS values of beef jerky with different drying methods during storage

\begin{tabular}{|c|c|c|c|c|}
\hline \multirow{2}{*}{ Treatment } & \multicolumn{3}{|c|}{ Storage $(\mathrm{d})$} & \multirow{2}{*}{ SEM $^{1)}$} \\
\hline & 0 & 10 & 20 & \\
\hline & \multicolumn{4}{|l|}{$\mathrm{pH}$} \\
\hline Hot air & $6.25^{\mathrm{a}}$ & $6.20^{\mathrm{a}}$ & $6.28^{\mathrm{a}}$ & 0.02 \\
\hline Sun-dried & $6.03^{b}$ & $5.94^{\mathrm{b}}$ & $6.01^{\mathrm{b}}$ & 0.03 \\
\hline Shade-dried & $6.03^{b}$ & $6.04^{\mathrm{b}}$ & $5.97^{\mathrm{b}}$ & 0.02 \\
\hline \multirow[t]{2}{*}{ SEM } & 0.07 & 0.08 & 0.10 & \\
\hline & \multicolumn{4}{|c|}{ TBARS (mg malonedialdehyde/kg) } \\
\hline Hot air & $0.68^{\mathrm{y}}$ & $1.94^{\mathrm{abx}}$ & $2.07^{\mathrm{x}}$ & 0.08 \\
\hline Sun-dried & $0.77^{\mathrm{y}}$ & $2.05^{\mathrm{ax}}$ & $2.06^{\mathrm{x}}$ & 0.08 \\
\hline Shade-dried & $0.74^{\mathrm{z}}$ & $1.73^{\text {by }}$ & $2.19^{\mathrm{x}}$ & 0.11 \\
\hline SEM & 0.03 & 0.04 & 0.08 & \\
\hline
\end{tabular}

${ }^{1)}$ Standard error of the means $(n=12)$

${ }^{\mathrm{a}, \mathrm{b}}$ Figures with different letters within the same column differ significantly $(p<0.05)$.

${ }^{\mathrm{x}-\mathrm{z}}$ Figures with different letters within the same row differ significantly $(p<0.05)$. eral studies have demonstrated that $\mathrm{pH}$ values of beef jerky samples decreased slightly during the storage periods (Okonkwo et al.,1992). According to Leistner (1987), spoilage of various dried meat products by mold growth can be inhibited or delayed by a lowering $\mathrm{pH}$.

TBARS value is the most common indicator used to measure the degree of lipid oxidation in meat products (Chen et al., 2004). There were no significantly differences in TBARS value during storage between control and treatments (Table 3). The shade-dried jerky showed significantly lower TBARS value than sun-dried sample after storage of $10 \mathrm{~d}(p<0.05)$. This may be due to the fact that shade-dried one is not directly exposed to the sun, which can cause lipid oxidation. This indicates that sundried jerky is more susceptible to lipid oxidation and higher temperature than shade-dried one during storage. Lee et al. (1997) point out that drying temperature and time had a great influence on the lipid oxidation of jerky and TBARS values showed high levels as drying temperature and time increased. However, there were no significantly differences observed in TBARS values after storage of $20 \mathrm{~d}$ between the treatments. The TBARS value of all jerky samples increased during storage, regardless of various drying methods $(p<0.05)$. It is normally accepted that TBARS value increases in meat with increasing storage time (Jung et al., 1994; Yang et al., 2009). Chen et al. (2004) noted that as $a_{w}$ value decreases there was a proportional increase of lipid oxidation and this is closely related to the presence of $\mathrm{NaCl}$ which acts as pro-oxidant (Torres et al., 1994). It is assumed that drying methods had little influence on the lipid oxidation of jerky from these results.

\section{Color measurements}

Meat color is one of the most important quality traits and could be affected by a number of factors such as $\mathrm{pH}$, protein denaturation, and water content (Feiner, 2006; Young and West, 2001). Color values of beef jerky with different drying methods during storage are shown in Table 4. Hot air-dried jerky showed a significantly lower lightness $\left(\mathrm{L}^{*}\right)$ than sun-dried and shade-dried ones $(p<$ $0.05)$. Sun-dried samples showed a significantly higher redness $\left(\mathrm{a}^{*}\right)$ and yellowness $\left(\mathrm{b}^{*}\right)$ than hot air and shadedried $(p<0.05)$. This may be due to the fact that sun-dried jerky could be attributed to photochemical reaction of sun. The findings of this study agree with Park and Park (2007) noted that meat color values $\left(L^{*}, a^{*}\right.$ and $\left.b^{*}\right)$ were higher in the air-blast dried beef jerky than in the hot airdried samples and the drying methods showed the great- 
Table 4. CIE color values of beef jerky with different drying methods during storage

\begin{tabular}{lcccc}
\hline \hline \multirow{2}{*}{ Treatment } & \multicolumn{3}{c}{ Storage (d) } \\
\cline { 2 - 3 } & 0 & 10 & 20 \\
SEM
\end{tabular}

${ }^{1)}$ Standard error of the means $(n=12)$

${ }^{\mathrm{a}, \mathrm{b}}$ Figures with different letters within the same column differ significantly $(p<0.05)$.

${ }^{x-z}$ Figures with different letters within the same row differ significantly $(p<0.05)$.

est effect on the redness $\left(a^{*}\right)$. Sherwin and Labuza (2003) showed that discoloration of jerky products could be affected by temperature. It is assumed that hot air and shade-dried jerky might have a discoloration due to the high temperature in hot air-dried and drying for a long time in shade-dried. Lee and Park (2004) noted that natural drying showed a higher meat color values $\left(\mathrm{L}^{*}, \mathrm{a}^{*}\right.$ and $\mathrm{b}^{*}$ ) than hot air-drying. Lee et al. (1997) investigated that as drying temperature and time increased, meat color values $\left(L^{*}, a^{*}\right.$ and $\left.b^{*}\right)$ maintained high levels. From the results, as the storage period increased, all treatments caused a significant decrease in $\mathrm{a}^{*}(p<0.05)$. The findings of the study agree with Teixeira et al. (2011) who air drying in meat samples could reduce $L^{*}$ and $b^{*}$ values, which became less luminous, yellow and vivid.

\section{Shear force values}

Texture in the jerky products has an important role in quality perception, and determines market attractiveness of this type of product (Konieczny et al., 2007). Shear force values of beef jerky samples with different drying methods during time are presented in Table 5. There was no significant difference observed in shear force values at $0 \mathrm{~d}$ of storage, regardless of drying methods. As the storage period increased, hot air-dried jerky caused a significant increase in shear force values $(p<0.05)$. The hot air-
Table 5. Shear force of beef jerky with different drying methods during storage

\begin{tabular}{lrcrr}
\hline \hline \multirow{2}{*}{ Treatment } & \multicolumn{3}{c}{ Storage (d) } & \multirow{2}{*}{ SEM $^{1)}$} \\
\cline { 2 - 4 } & 0 & 10 & 20 \\
\hline & \multicolumn{3}{c}{ Shear force $(\mathrm{g})$} \\
Hot air & $16,709^{\mathrm{z}}$ & $18,918^{\mathrm{ay}}$ & $21,209^{\mathrm{ax}}$ & 899 \\
Sun-dried & 15,912 & $15,074^{\mathrm{b}}$ & $14,999^{\mathrm{b}}$ & 1,470 \\
Shade-dried & 15,299 & $14,313^{\mathrm{b}}$ & $13,712^{\mathrm{b}}$ & 462 \\
SEM & 507 & 449 & 1,452 & \\
\hline
\end{tabular}

${ }^{1)}$ Standard error of the means $(n=12)$

${ }^{a, b}$ Figures with different letters within the same column differ significantly $(p<0.05)$.

${ }^{x-z}$ Figures with different letters within the same row differ significantly $(p<0.05)$.

dried jerky showed significantly higher shear force values than sun-dried and shade-dried samples after storage of 10 and $20 \mathrm{~d}(p<0.05)$. This could be due to the fact that hot air-dried jerky occurs in drying by high temperature, which is attributed to denaturation and coagulation of the meat protein. Too short or too long a drying time resulted in a distinct deterioration of texture attributes yielding products that were described as either too soft or too hard and brittle (Konieczny et al., 2007). Yang et al., (2009) evaluated the shear force values decreased with storage time in beef jerky samples with air drying. From this result, natural drying method such as sun and shade-drying seems to be more recommended than hot air drying method.

\section{Microbiological analysis}

Changes in total plate counts and E. coli. of beef jerky with different drying methods during storage are provided in Table 6 . The total microbial counts of jerky were within a range of low level from 2 to $3 \log \mathrm{CFU}$ at $0 \mathrm{~d}$ of storage. There were no significant differences observed TPC at $0 \mathrm{~d}$ of storage, regardless of the drying condition. However, TPC of shade-dried jerky was significantly higher than hot-air and sun-dried jerky after storage of $10 \mathrm{~d}$ $(p<0.05)$. Also, TPC of sun-dried and shade-dried jerky was significantly higher than hot air-dried jerky after storage of $20 \mathrm{~d}(p<0.05)$. TPC of sun-dried and shade-dried samples was 4.81 and 5.03 Log CFU, respectively after $20 \mathrm{~d}$ of storage. Yang and Lee (2002) evaluated that TPC of domestic and imported commercial beef jerky was within 3 to 4 Log CFU range. Jung et al. (1994) reported that TPC of beef jerky was within 4 to 5 Log CFU range after storage of $3 \mathrm{w}$, which this finding was in correspondence to these criteria in this experiment. E. coli was not detected in all treatments in this experiment. Microbial growth could deteriorate the meat and meat 
Table 6. Total plate counts (TPC) and $E$. coli of beef jerky with different drying methods during storage

\begin{tabular}{|c|c|c|c|c|}
\hline \multirow{2}{*}{ Treatment } & \multicolumn{3}{|c|}{ Storage (d) } & \multirow{2}{*}{$\mathrm{SEM}^{1)}$} \\
\hline & 0 & 10 & 20 & \\
\hline \multicolumn{5}{|c|}{ TPC (Log CFU) } \\
\hline Hot air & 2.47 & $2.53^{\mathrm{b}}$ & $3.30^{\mathrm{b}}$ & 0.28 \\
\hline Sun-dried & $2.80^{y}$ & $2.57^{\text {by }}$ & $4.81^{\mathrm{ax}}$ & 0.45 \\
\hline Shade-dried & $3.52^{\mathrm{y}}$ & $3.42^{\text {ay }}$ & $5.03^{\mathrm{ax}}$ & 0.48 \\
\hline SEM & 0.31 & 0.30 & 0.51 & \\
\hline \multicolumn{5}{|c|}{ E. coli (Log CFU) } \\
\hline Hot air & $\mathrm{ND}^{2)}$ & ND & ND & \\
\hline Sun-dried & ND & ND & ND & \\
\hline $\begin{array}{l}\text { Shade-dried } \\
\text { SEM }\end{array}$ & ND & ND & ND & \\
\hline
\end{tabular}

${ }^{1)}$ Standard error of the means $(n=12)$

${ }^{2)}$ Not detected

${ }^{\mathrm{a}, \mathrm{b}}$ Figures with different letters within the same column differ significantly $(p<0.05)$

${ }^{\mathrm{x}, \mathrm{y}}$ Figures with different letters within the same row differ significantly $(p<0.05)$.

products quality. We found that natural drying (sun and shade-dried) method have a potential contamination from bacteria due to the low drying temperature (FSIS, 2011; Park and Park, 2007). The low microbial levels seem to be due to the fact that microbial growth is inhibited at low $\mathrm{a}_{\mathrm{w}}$ (Gould and Christian, 1988; Hocking, 1988; Torres et al., 1994). The water activity, which is the measure of the free water present in food products, can sustain the growth of microorganisms (Choi et al., 2008). Faith et al. (1998) investigated that drying using dehydrator in beef jerky was effective for reducing pathogen numbers by at least $5 \mathrm{Log} \mathrm{CFU} / \mathrm{g}$ at $52-68^{\circ} \mathrm{C}$, with longer drying times required to achieve this reduction at the lower temperatures compared with the higher temperatures. It is speculated that the growth of microorganisms can be efficiently controlled and inhibited by additional drying, treatment of antimicrobial or organic acid and vacuum packaging and so on. Presently, there is no legal limit for total aerobic counts in preserving dried meats such as jerky products on standards for processing and ingredients specifications of livestock products in Korea (QIA Notification, 2011). Regulation in jerky should be established by government authority for meat safety limits. Taking drying methods into account, additional research on the microbiological safety of the jerky is needed. Even though natural drying seems to be more susceptible to microbiological contamination than the hot-air, the microbiological problem can be controlled by more antimicrobial additives or controlled process environment.
Table 7. Sensory evaluation ${ }^{1)}$ of beef jerky with different drying methods after $10 \mathrm{~d}$ of storage

\begin{tabular}{lcccc}
\hline \hline \multirow{2}{*}{ Treatment } & \multicolumn{3}{c}{ Storage $(\mathrm{d})$} & \multirow{2}{*}{ SEM $^{2)}$} \\
\cline { 2 - 4 } & Hot air & Sun-dried & Shade-dried \\
\hline Color & $5.06^{\mathrm{b}}$ & $6.60^{\mathrm{a}}$ & $5.66^{\mathrm{b}}$ & 0.23 \\
Flavor & 5.73 & 5.13 & 5.06 & 0.23 \\
Tenderness & $3.20^{\mathrm{b}}$ & $4.55^{\mathrm{a}}$ & $4.86^{\mathrm{a}}$ & 0.51 \\
Juiciness & $3.40^{\mathrm{b}}$ & $4.53^{\mathrm{a}}$ & $4.60^{\mathrm{a}}$ & 0.25 \\
Acceptability & $3.66^{\mathrm{b}}$ & $4.53^{\mathrm{ab}}$ & $5.00^{\mathrm{a}}$ & 0.38 \\
\hline 1) 1 , extremely bad $\sim 9$, extremely good \\
${ }^{2}$ Standard error of the means $(n=12)$ \\
${ }^{\text {a,b }}$ Figures with different letters within the same row differ signifi- \\
cantly $(p<0.05)$.
\end{tabular}

\section{Sensory evaluation}

The most important sensory attributes of jerky are texture, color and flavor, which are determined by the raw material and numerous technological factors (Albright $e t$ al., 2000). The sensory panels were convened to assess the effects on the color, flavor, juiciness, tenderness and overall acceptability of beef jerky with different drying methods after $10 \mathrm{~d}$ of storage (Table 7). There were no significant differences observed in color and flavor of beef jerky. However, the sun-dried and shade-dried jerky showed significantly higher tenderness, juiciness and overall acceptability scores than hot air-dried samples $(p<0.05)$. In case of hot air-dried samples, it can be attributed to the excessive drying and losing moisture on the meat surface caused by high temperature during the hot air-drying. This explanation can be supported by Comaposada et al. (2000) who suggested if the $\mathrm{a}_{\mathrm{w}}$ on the surface is high, an increase in temperature would produce a decrease in the water content and this would accelerate the drying of the inner zones of the product. Lee and Park (2004) observed that hot air-drying showed a higher hardness and chewiness than natural drying. Miller (1994) pointed out that Warner-Bratzler shear force values were highly correlated with overall tenderness of muscle. The findings on the sensory traits of jerky indicate that natural drying method such as sun and shade-drying seems to be superior quality than hot air drying method.

\section{Acknowledgements}

This research was jointly supported by the 2011 2012 Rural Development Administration (No. PJ-907235052012), and by the Technology Development Program for Agriculture and Forestry (No. 311016-3), Republic of Korea. 


\section{References}

1. Ahn. D. U., Olson, D. G., Jo. C., Chen. X., Wu. C. and Lee, J. I. (1998) Effect of muscle type, packaging, and irradiation on lipid oxidation, volatile production, and color in raw pork patties. Meat Sci. 49, 27-39.

2. Albright, S. N., Kendall, P. A., and Sofos, J. N. (2000) Sensory properties of beef jerky processed under various conditions. In Proceedings of IFT annual meeting, June 10-14, Dallas, TX, USA, Session 11.

3. Albright, S. N., Kendall, P. A., Avens, J. S., and Sofos, J. N. (2003) Pretreatment effect on inactivation of Escherichia coli O157:H7 inoculated beef jerky. LWT-Food Sci. Technol. 36, 381-389.

4. AOAC (2000) Official methods of analysis (17th ed.). Gaithersburg, MD: Association of Official Analytical Chemists.

5. Barrett, A. H., Briggs, J., Richardson, M., and Reed, T. (1998) Texture and storage stability of processed beef sticks as affected by glycerol and moisture levels. J. Food Sci. 63, 8487.

6. Bone, D. P. (1973) Awin intermediate moisture foods. Food Technol. 27, 71-76

7. Calicioglu, M., Sofos, J. N., and Kendall, P. A. (2003) Influence of marinades on survival during storage of acid-adapted and non adapted Listeria monocytogenes inoculated postdrying on beef jerky. Int. J. Food Microbiol. 86, 283-292.

8. Chang, F. S., Huang, T. C., and Pearson, A. M. (1996) Control of the dehydration process in production of intermediate moisture meat products: a review. Adv. Food Nutri. Res. 39, $71-114$.

9. Chen, W. S., Lin, D. C., and Chen, M. T. (2004) Determination of quality changes throughout processing steps in Chinese-style pork jerky. Asian-Aust. J. Anim. Sci. 17, 700-704.

10. Choi, J. H., Jeong, J. Y., Han, D. J., Choi, Y. S., Kim, H. Y., Lee, M. A., Lee, E. S., Paik, H. D., and Kim, C. J. (2008) Effects of pork/beef levels and various casings on quality properties of semi-dried jerky. Meat Sci. 71, 278-286.

11. Comaposada, J., Gou, P., and Arnau, J. (2000) The effect of sodium chloride content and temperature on pork meat isotherms. Meat Sci. 55, 291-295.

12. Edward, S. D. and Pauline, E. M. (1965) Comparison of beta-carotene content of dried carrots prepared by three dehydration process. Food. Technol. 19, 1597-1603.

13. Faith, N. G., Le Coutour, N. S., Alvarenga, M. B., Calicioglub, M., Buegeb, D. R. and Luchansky, J. B. (1998) Viability of Escherichia coli O157:H7 in ground and formed beef jerky prepared at levels of 5 and $20 \%$ fat and dried at 52, 57, 63 , or $688 \mathrm{C}$ in a home-style dehydrator. Int. J. Food Microbiol. 41, 213-221.

14. Farouk, M. M. and Swan, J. E. (1999) Boning and storage temperature effects on the attributes of soft jerky and frozen cooked free-flow mince. J. Food Sci. 64, 465-468.

15. Feiner, G. (2006) Color in fresh meat and in cured meat products. Meat products handbook: Practical science and technology. Cambridge: Woodhead Publishing. pp. 142-157.

16. Fernández-Salguero, J., Gómez, R., and Carmona, M. A. (1994)
Awof Spanish intermediate-moisture meat products. Meat Sci., 38, 341-346.

17. FSIS (2011) Jerky and Food safety. Food Safety and Inspection Service, United States Department of Agriculture, Washington, DC, USA. Available from: http://www.fsis.usda.gov/ Fact_Sheets/Jerky_and_Food_Safety/index.asp\#1. Modified Nov. 15, 2011

18. Gould, G. W. and Christian, J. H. B. (1988) Characterization of the state of water in foods biological aspects. In: Food preservation by moisture control. Seow, C. C. (ed.) Elsevier Applied Science, London, pp. 43-56.

19. HACCP Generic Model - Dried Meats (Beef Jerky) (1997) CFIA, ACIA Report, October 1997, Canada, pp. 1-35.

20. Hocking, A. D. (1988) Mould and yeast associated with foods of reduced water activity: Ecological interactions. In C. C. Seow (Ed.), Food preservation by moisture control. London: Elsevier Applied Science. pp. 57-72.

21. Holdsworth, S. D. (1971) Dehydration of food products. $J$. Food Technol. 6, 331-338.

22. Igene, J. O., Farouk, M. M., and Akanbi, C. T. (1990). Preliminary studies on the traditional processing of Kilishi. $J$. Sci. Food Agri. 50, 89-98.

23. Jose, F. S., Rafael, G., and Miguel, A. C. (1994) Awof Spanish intermediate moisture meat products. Meat Sci. 38, 341350 .

24. Jung, S. W., Baek, Y. S., Kim, Y. S., and Kim, Y. H. (1994) Quality changes of beef jerky during storage. Korean $J$. Anim. Sci. 36, 683-697.

25. Karel, M., Fennerma, O. R., and Lund, D. B. (1978) Physical principles of food preservation, Marcel Dekker, Boston, pp. 255-328.

26. Kim, M. H. (1990) Effects of pretreatments prior to conventional dehydration on dried product quality. Biochem. Eng. J. 4, 30-38.

27. Konieczny, P., Stangierski, J., and Kijowski (2007) Physical and chemical characteristics and acceptability of home style beef jerky. Meat Sci. 76, 253-257.

28. Lee, S. K., Kim, H. J., Kang, C. G., and Kim, S. T. (1997) Effects of temperature and time on physicochemical properties of Korean goat meat jerky during drying. Korean J. Food Sci. An. 17, 184-189.

29. Labelle, R. L. and Moyer, J. C. (1966) Dehydrofreezing red tart cherries. Food Technol. 20, 1345-1352.

30. Lee, S. W. and Kang, C. S. (2003) Effects of moisture content and drying temperature on the physicochemical properties of ostrich jerky. Nahrung Food 47, 330-333.

31. Lee, S. J. and Park, G. S. (2004) The quality characteristics of beef jerky prepared with various spices. Kor. J. Food Cookery Sci. 20, 489-497.

32. Leistner, L. (1987) Shelf stable product and intermediate moisture foods based on meat. In Rockland, L. and Beuchat, L. B. (eds.), Awtheory and application to food, Marcel Dekker Inc, New York, pp. 295-328.

33. Miller, M. S. (1994) Proteins as fat substitutes. In: Hettiarachchy, N. S. and Ziegler, G. R. (eds.), Protein functionality in food system. Marcel Dekker Inc, New York. 
34. Miller, M. F., Davis, G. W., Ramsey, C. B., and Irizarry, H. (1996) Awtheory and application to food. In: Rockland, L. B. and Beuchat, L. R. (eds). Marcel Dekker, New York, USA, pp. 295-328.

35. Okonkwo, T. M., Obanu1, Z. A., and Ledward, D. A. (1992) Characteristics of some intermediate moisture smoked meats. Meat Sci. 31, 135-145.

36. Park, G. S., Lee, S. J., and Jeong, E. S. (2002). The quality characteristics of beef jerky according to the kinds of saccharides and the concentrations of green tea powder. J. Kor. Soc. Nutr. 31, 230-235.

37. Park, C. J. and Park, C. S. (2007). The effects of drying method and spice extracts added to beef jerky on the quality characteristics of beef jerky. Korean J. Food Cookery Sci. 23, 800809.

38. Park, C. J., Kim, M. L., and Park, C. S. (2009). Effect of drying method and medicinal herb extract addition on the microstructure of beef jerky. Korean J. Food Preserv. 16, 875-883.

39. Paterson, B. C. Parrish, F. C., and Stromer, M. H. (1988) Effect of salt and pyrophosphate on the physical and chemical properties of beef muscle. J. Food Sci. 53, 1258-1265.

40. QIA Notification (2011) Standards for processing and ingredients specifications of livestock products, Quarntine and Inspection Agency.

41. Quinton, R. D., Cornforth, D. P., Hendricks, D. G., Brennand, C. P., and Su, Y. K. (1997) Acceptability and composition of some acidified meat and vegetable stick products. J. Food Sci. 62, 1250-1254.

42. SAS (1999) SAS/STAT Software for PC. Release 6.11, SAS Institute, Cary, NC, USA.

43. Sherwin, C. P. and Labuza, T. P. (2003). Role of moisture in maillard browning reaction rate in intermediate moisture foods: Comparing solvent phase and matrix properties. $J$. Food Sci. 68, 588-594.

44. Teixeira, A. Pereira, E., and Rodrigues. E. S. (2011) Goat meat quality. Effects of salting, air-drying and ageing processes. Small Rumin. Res. 98, 55-58.

45. Torres, E. A. F. S., Shimokomaki, M., Franco, B. D. G. M., Landgrafa, M., Carvalho, B. C., and Santos, J. C. (1994) Parameters determining the quality of charqui, an intermediate moisture meat products. Meat Sci., 38, 229-234.

46. Yamaguchi, N., Naito, S., Okada, Y., and Nagase, A. (1986) Effect of oxygen barrier of packaging material on food preservation. Annual Report of the Food Research Institute, 27. Japan: AichiPrefecture Government. pp. 69-73.

47. Yang, C. Y. and Lee, S. H. (2002). An evaluation of quality of the marketing jerky in domestic. I. Investigation of outward appearance, food additives, nutrient content and sanitary state. Korean J. Food Nutri. 15, 197-202.

48. Yang, H. S., Hwang, Y. H., Joo, S. T., and Park. G. B. (2009) The physicochemical and microbiological characteristics of pork jerky in comparison to beef jerky. Meat Sci. 82, 289294.

49. Yoon, Y., Calicioglua, M., Kendallb, P. A., Smitha, G. C., and Sofos, J. N. (2005) Influence of inoculum level and acidic marination on inactivation of Escherichia coli O157:H7 during drying and storage of beef jerky. Food Microbiol. 22, 423-431.

50. Young, O. A. and West, J. (2001). Meat color (Eds.), Meat Science and Applications. New York: Marcel Dekker, Inc. pp. 39-69.

(Received 2012.3.13/Revised 2012.5.21/Accepted 2012.6.29) 